УДК 343.985

DOI https://doi.org/10.32837/pyuv.v2i3(28).383

\author{
В. В. Семеногов \\ кандидат юридичних наук, доцент, \\ доиент кафедри криліналістики \\ Національного юридичного університету ілені Ярослава Мудрого
}

\title{
ТАКТИЧНІ ОСОБЛИВОСТІ ОБШУКУ ПІД ЧАС РОЗСЛІДУВАННЯ ІНСЦЕНОВАНИХ ВБИВСТВ
}

Криміногенна обстановка в Україні характеризується зростанням чисельності злочинів, що вирізняються старанністю підготовки, витонченістю вибору способів учинення і приховування, зухвалістю й жорстокістю. На особливу увагу заслуговують насильницькі й корисливо-насильницькі злочини, оскільки саме вони спрямовані проти найважливішого для людини - ¥ї життя i здоров'я, являють собою загрозу суспільству й державі. Вбивства взагалі завжди мають у суспільстві особливий резонанс. Низький духовний і матеріальний рівень розвитку суспільства, правовий нігілізм залишають свій негативний відбиток на розвитку держави й кожного їі громадянина. Бажання легкої наживи, озлобленість, байдужість до всього - далеко не вичерпний перелік причин, які визначають посягання на життя людини.

Зміни,щовідбуваютьсявданийчасусуспільстві, реформування в різних сферах діяльності породили загострення криміногенної обстановки, виникнення нових видів злочинної діяльності. До числа злочинів, які є особливо небезпечними, сьогодні належать убивства, приховані інсценуванням.

За загального зростання чисельності вбивств, учинених як окремими особами, так і організованими групами, мають місце й убивства, приховані інсценуванням, розслідування яких становить особливу складність. У цьому зв'язку вбачається важливим і необхідним формування окремих рекомендацій, щодо тактики проведення деяких слідчих (розшукових) дій.

Вагомий внесок у дослідження теоретичних проблем, пов'язаних із розслідуванням убивств, зокрема тих, що приховуються інсценуванням, зробили вчені-криміналісти України й інших держав. Проблемні питання розслідування вбивств розглядаються в дослідженнях таких знаних науковців, як: Ю.П. Аленін, В.П. Бахін, Р.С. Бєлкін, О.Ю. Булулуков, І.В. Борисенко, О.М. Васильєв, Л.Г. Видонов, В.Г. Гончаренко, А.В. Дулов, В.А. Журавель, А.В. Іщенко, В.П. Колмаков, О.Н. Колесниченко, В.О. Коновалова, В.С. Кузьмичов, В.К. Лисиченко, В.Г. Лукашевич, Г.А. Матусовський, Г.М. Мудьюгін, М.В. Салтевський, В.В. Тіщенко, В.Ю. Шепітько й ін.

Актуальність теми визначається нагальною потребою аналізу існуючих тактичних прийомів обшуку з метою надання обгрунтованих рекомен- дацій щодо вдосконалення й розробки тактичних комбінацій розглядуваної слідчої (розшукової) дії, тактики обшуку загалом.

Обшук у справах про вбивства, приховані інсценуванням, має свою специфіку, що визначається видом інсценування, слідчою ситуацією і ситуацією обшуку. Висунувши версію про вид інсценування, слідчий встановлює об'єкти пошуку та відповідні об'єкти обшуку. За інсценування природної смерті без наявності на тілі загиблого слідів насильства, спираючись на результати експертизи про причину смерті, він визначає перелік предметів, що підлягають відшуканню. Якщо має місце отруєння, доцільно шукати отруту, інші хімічні сполуки, медичні препарати, здатні у великій кількості призвести до летального результату, речовини, якими могло бути спричинено отруєння. Необхідно відшукувати посуд (тару), у якому могли зберігатися ці речовини, а також з урахуванням способу попадання їх в організм жертви знайти і долучити до матеріалів провадження як речові докази ті предмети, безпосередньо з яких отрута потрапила в нутро жертви. Це можуть бути чашки, пляшки, аерозольні балончики. У разі встановлення, що отрута потрапила в організм жертви шляхом ін'єкцій треба шукати шприци, крапельниці, за допомогою яких була введена отрута в організм.

Об’єктами обшуку в такому разі можуть бути квартира загиблого, місце виявлення трупа, місце останнього перебування жертви, квартири родичів, близьких, знайомих, у яких є можливість знайти перелічені предмети.

Розглядаючи інсценування самогубства чи нещасного випадку, варто з особливою уважністю поставитися до визначення причини смерті, оскільки саме ця обставина впливає на напрям обшуку. Насамперед важливо відшукати передсмертну записку, за наявності якої обов'язково треба залучити до матеріалів справи вільні зразки почерку, необхідні для проведення почеркознавчої експертизи, а за підозри фальсифікації необхідно відібрати в підозрюваного вільні й експериментальні зразки.

Спираючись на визначення способу позбавлення життя, зокрема в разі повішення, необхідно шукати матеріал, з якого виготовлено зашморг, тому що цілком імовірно, що мотузка, з якої виго- 
товлена петля, є частиною мотка, який може бути виявлено як у загиблого, так і в підозрюваного. У разі інсценування самогубства з використанням холодної зброї потрібно відшукати предмет, яким завдано ушкодження. Аналогічно треба діяти і за настання смерті внаслідок використання вогнепальної зброї. Інсценувавши самогубство за допомогою вогнепальної зброї, підозрюваний залишить її на місці вбивства, знищивши свої відбитки пальців. Однак існує ймовірність виявлення боєприпасів до цієї зброї не в загиблого, а саме в підозрюваного. Виявлення під час обшуку в загиблого вогнепальної зброї з невикористаними боєприпасами чи використання ним іншої зброї, що йому не належить, буде негативною обставиною, що свідчить про інсценування.

Інсценування нещасного випадку, як-от падіння з висоти, утоплення, нещасний випадок на виробництві чи будь-який інший спосіб позбавлення життя, вимагає від слідчого відшукання речей, предметів, з якими міг контактувати загиблий безпосередньо до події, що трапилася. Якщо встановлено особу, підозрювану в убивстві, у процесі обшуку в неї повинні бути виявлені знаряддя вбивства, одяг, у якому вона була в момент злочину, оскільки на ньому могли залишитися сліди, що вказують на контакт із жертвою. Це сліди крові, слини, інші біологічні виділення людини, різні мікрочастинки: волокна одягу, сліди нашарування, волосся, сліди від укусу, подряпини, інші сліди боротьби, мікрочастинки грунту, грунту з місця події тощо. Може бути й навпаки: на речах і предметах убитого могли залишитися частки, що належать підозрюваному. Виявленню підлягають також предмети, що використовувалися для приховування вбивства шляхом інсценування, а також переписка, щоденники, нотатки, записні книжки й інші документи, що можуть допомогти визначити характер взаємин потерпілого із близькими, виявити серед останніх особу, заінтересовану в його смерті.

Успіх обшуку багато в чому залежить від ретельної підготовки до його проведення. Необхідно зібрати якнайбільше інформації про особу, яка обшукується, ознайомитися з місцем (місцевістю), приміщенням, де відбуватиметься обшук, з метою необхідної орієнтації на місцевості. Під час підготовки до обшуку варто висувати пошукові верciї щодо місця знаходження шуканого. Ці версії $\epsilon$ різновидом пошукових версій. Усі вони у своїй побудові грунтуються на відповідній інформації, відрізняючись у першому випадку ширшим діапазоном пошукових дій і визначеністю розшукуваного об'єкта (особи). У процесі обшуку місце пошукових дій обмежено житловим приміщенням, ділянкою місцевості, однак водночас не завжди є чіткий об'єкт пошукових дій, тому що він не визначений, хоча й зумовлений видом і механізмом учинення злочину.
I в першому, і у другому випадках розшуку головна роль належить рефлексивному мисленню слідчого, який імітує мислення осіб - як тих, що сховалися, так і тих, хто ховає розшукувані об'єкти. Високим рівнем рефлексії протиборчих осіб визначається перемога однієї з них [5, с. 67; 7, с. 116]. Чим точніше буде визначено предмет обшуку, тим конкретнішою буде пошукова версія. Остання є результатом узагальнення розумової діяльності слідчого з виявлення розшукуваного, наслідком якого є припущення про місце його приховання.

Для виявлення розшукуваних слідів і об'єктів дуже важливо мати уявлення про специфіку психології особи, яка щось приховує. Як уже зазначалося раніше, слідчий, здійснюючи обшук, повинен правильно використовувати можливості рефлексивного мислення.

До числа завдань, що вирішує обшукуваний, належить насамперед обрання місця приховування. Зазвичай воно обмежується місцем проживання злочинця і територією подвірних будівель. Обрання місця приховування багато в чому залежить від інтелектуальних можливостей того, хто ховає, i, звичайно ж, від розмірів і особливостей приховуваної речі. Злочинці обирають місяця приховування, що не відповідаютьне нормальним, звичайним уявленням, тобто ті місця, що виходять за рамки загальноприйнятих людських розумових стандартів.

В.О. Коновалова зазначає, що під час обрання найбільш надійного місця для приховання чимале значення мають професійні навички і знання особи. Професійні навички відкривають можливість для використання 3 метою приховування тих місць, які відомі особі у зв'язку з її професією. Причому вони характеризуються оригінальністю, що випливає 3 тонкостей професії, про які знає тільки особа, яка володіє нею. Ось чому орієнтація на використання професійних нахилів під час відшукання прихованого нерідко вимагає від слідчого поглибленого уявлення про особливості професії особи, а також консультації з фахівцями щодо того, які дані професійних навичок можуть бути використані для спорудження схованок тощо. Однак орієнтація на професію особи, у якої має бути здійснено обшук, не повинна обмежувати територію обшуку.

Друге завдання, яке вирішує той, хто ховає, це маскування місця приховування. Одним 3 інтелектуальних завдань для того, хто приховує, є приведення цього місця у природний стан, що не повинен привертати уваги, отже, і викликати підозру. Але прагнення злочинця замаскувати місце приховування у психологічному відношенні нерідко гіперболізується, тому призводить до створення надмірно маскувального спорудження, яке через явні безглуздість і надмірність привер- 
тає більш пильну увагу й підозру особи, яка здійснює обшук [6, с. 25]. Це може бути терміновий ремонт квартири, хоча попередній був зовсім недавно, свіжопофарбована чи оновлена підлога або ïi частина, новий кахель у ванній кімнаті тощо. До такого маскування зазвичай злочинці вдаються з метою приховати сліди крові.

Однак існує й таке поняття, як квазімаскування, яке має місце, коли злочинець не ховає розшукувані речі, знаряддя вбивства, а навпаки, намагається виставити їх на видне місце, тим самим дезорієнтувати того, хто шукає. Наприклад, ваза, якою завдано смертельні поранення жертві, скинутої з висоти з метою інсценування самогубства, може стояти на своєму звичному місці на столі, у ній можуть бути квіти. Але на ній могли залишитися сліди крові, інші мікрочастинки, що вказують на те, що саме ця ваза була знаряддям убивства.

Третє завдання, розв'язуване злочинцем, - обрання лінії поведінки. Вона може передувати як самому злочину, так і обшуку, а може й супроводжувати ці дії. Особа, яка задумала вчинити вбивство з наступним інсценуванням, залежно від останнього поширюе неправдиві відомості. Водночас складність вибору лінії поведінки обшукуваного під час здійснення обшуку пояснюється й тим, що він не знає, яким буде обшук, як буде поводитися особа, яка провадить обшук, та ін. Обшукуваний намагається своєю поведінкою не видати шукану річ, заздалегідь внутрішньо готується до обшуку, продумує свої відповіді на можливі запитання, налаштовується морально, у процесі всієї слідчої дії змушений коректувати свою поведінку стосовно конкретної ситуації обшуку, що, у свою чергу, допомагає слідчому правильно обрати манеру поводження. Під час здійснення обшуку слідчий повинен уважно стежити за довільними і мимовільними реакціями обшукуваного на різні подразники. Це може бути надмірне хвилювання, що виявляється в заїкуватості, раптовому потовиділенні, безперервному ходінні по квартирі або, навпаки, раптовому припиненні спілкування, зайвої зосередженості тощо.

Під час обшуку слідчому рекомендується не просто шукати, а діяти, використовуючи тактичні і психологічні прийоми, постійно впливаючи на обшукувану особу. Подразники з боку слідчого мають словесний вираз. Це впевненість слідчого у приховуванні шуканої речі й у відшуканні прихованого. Звертання уваги на окремі предмети, ретельне їх вивчення також є подразниками для обшукуваного. У бесіді з обшукуваною особою слідчий провадить «словесну розвідку» - тактичний прийом, за якого повідомляє про місце, де буде здійснено обшук, з метою викликати реакцію в обшукуваного. Дуже важливе повідомлення останнього про можливості технічних засобів, за допомогою яких провадитиметься обшук, що допоможе переконати його в недоцільності приховування. Як зазначає Г.І. Борягін, існують рекомендації щодо важливості і значення подразників, які мають характер радше емпіричний, аніж теоретичний, окрім окремих розробок у частині «словесної розвідки» [1, с. 122].

Слідчому належить виявляти повну впевненість в успішному завершені обшуку, вміти максимально зосередитися, мати високий рівень працездатності. Цьому сприяють відповідна підготовка слідчої дії, своєчасність її проведення, залучення необхідного числа помічників, фахівців, наявність необхідних технічних засобів. Особливо важливо не припиняти, а активізувати обшук у складних умовах: у забруднених приміщеннях, на горищах, у підвалах, серед нечистот і в різних важкодоступних місцях, маючи для цього спецодяг, технічні пристосування й ін. [4, с. 443].

Обшук повинен бути раптовим, що зумовлено тим, що злочинець може вдатися до знищення речей, слідів. Обшук має провадитися на відповідній стадії розслідування залежно від сформованої слідчої ситуації [2, с. 9-10; 3, с. 65-67]. Його результати можуть бути використані під час наступних допитів підозрюваного й обвинуваченого.

У процесі здійснення обшуку слідчому належить проаналізувати дії злочинця стосовно властивих йому психологічних, фізіологічних, професійних та інших особливостей, що допоможе уявити картину дій обшукуваного у процесі приховування шуканого.

Правильна оцінка поведінки обвинуваченого зазвичай визначає результативність обшуку, що особливо важливо для викриття інсценування.

\section{Jimepamypa}

1. Борягин Г.И. Некоторые вопросы психологии производства обыска. Труды Научно-исследовательского института милиции Министерства внутренних дел Союза Советских Социалистических Республик. Москва, 1959. № 1. С. 111-125.

2. Денисюк С.Ф. Система тактичних прийомів обшуку : автореф. дис. ... канд. юрид. наук: 12.00.09. Харків, 1999. $18 \mathrm{c.}$

3. Денисюк С.Ф., Шепитько В.Ю. Обыск в системе следственных действий (тактико-криминалистический анализ) : научно-практическое пособие. Харьков : Консум, 1999. С. 160.

4. Еникеев М.И. Основы общей и юридической психологии : учебник для вузов. Москва : Юристъ, 1996. C. 631 .

5. Коновалова В.Е. Версия: концепция и функции в судопроизводстве : монография. Харьков : ФЛП Вапнярчук Н.Н., 2007. 192 с.

6. Коновалова В.Е., Шепитько В.Ю. Обыск: тактика и психология : учебное пособие. Харьков : Гриф, 1997. С. 25.

7. Ратинов А.Р. Теория рефлексивных игр в приложении к следственной практике. Правовая кибернетика. Москва : Юрид. лит., 1970. С. 116. 


\section{Анотація}

Семеногов В. В. Тактичні особливості обшуку під час розслідування інсценованих вбивств. - Стаття.

Стаття присвячена досить важливій і актуальній темі не лише серед науковців, а і серед практичних працівників правоохоронних органів, яким досить часто доводиться здійснювати свою діяльність із розслідування злочинів, зокрема таких суспільно небезпечних, як убивства, в умовах подолання протидії щодо встановлення істини й викриття винних осіб. У статті проаналізовано поняття обшуку, розкрито його значення як невідкладної слідчої (розшукової) дії під час розслідування різних видів убивств.

У статті наголошено на необхідності слідчому виявляти повну впевненість в успішному завершені обшуку, уміти максимально зосередитися, мати високий рівень працездатності. Цьому сприяють відповідна підготовка слідчої дії, своєчасність її проведення, залучення необхідного числа помічників, фахівців, наявність необхідних технічних засобів

Акцентовано увагу на тому, що обшук у справах про вбивства, приховані інсценуванням, має свою специфіку, що визначається видом інсценування, слідчою ситуацією і ситуацією обшуку. Достатньо уваги приділено тактичним операціям, у яких центральне місце відведено обшуку і доцільності їх застосування. Не залишились без уваги й види обшуку, зокрема й відносно нові, як-от обшук-затримання, обшук із негативним результатом та ін. Виходячи зі слідчих ситуацій і виду вбивств, зроблено спробу виділити об'єкти обшуку та предмети пошуку з метою орієнтувати правоохоронні органи на те, що слід шукати й де. Дана робота містить рекомендації щодо застосування тактичних прийомів обшуку залежно від виду та способу вбивств. Акцентовано увагу на особливості тактики проведення обшуку під час розслідування таких убивств, як: убивства, що вчиняються організованими злочинними групами, убивства на замовлення, убивства із застосуванням вибухових пристроїв, убивства 3 розчленуванням, які мають ознаки інсценувань. Теоретичні положення, висловлені автором, ілюструються прикладами із практики розслідування, що наочно свідчить про беззаперечне значення обшуку в системі слідчих дій під час розслідування такого тяжкого злочину, як убивство.

Ключові слова: обшук, тактика обшуку, вбивство, інсценування, викриття інсценувань.

\section{Summary}

Semenogov $V . V$. Tactical features of the search in the staged killings investigation. - Article.

The article is devoted to a sufficiently important and relevant topic not only among scientists, but also among law enforcement officials, who often have to carry out their activities to investigate crimes, including such socially dangerous ones as murder, in the face of truth finding and perpetrators detection. The concept of search is analyzed in the article, its meaning is revealed as an urgent investigative action in the investigation of different types of killings.

The article emphasizes the need for the investigator to show full confidence in the successful completion of the search, to be able to focus as much as possible, to have a high level of efficiency. This is facilitated by appropriate preparation of the investigative action, timeliness of its conduct, involvement of the required number of assistants, specialists, availability of the necessary technical means.

Attention is drawn to the fact that the search, in cases of murders concealed by staging, has its own specificity, which is determined by the type of staging, the investigative situation and the situation of the search. Much attention has been paid to tactical operations that focus on search and the appropriateness of their use. The types of searches, including relatively new ones such as search-detention, search with a negative result and others, weren't also ignored. Based on investigative situations and the type of homicide it was made attempt to identify certain search objects and search items in order to orient law enforcement agencies to what to look for and where. This paper contains recommendations for the use of tactical methods of search, depending on the type and method of murder. The attention is paid to the peculiarities of the tactics of conducting searches in the investigation of such murders as: murders committed by organized crime groups, murders on the order, murders with use of explosive devices, murders with dismemberment, which contain signs of staging. The theoretical statements made by the author are illustrated by examples from the practice of investigation, which clearly demonstrates the indisputable value of the search in the system of investigative actions in the investigation of such serious crimes as murder.

Key words: search, search tactics, murder, staging, staging disclosure. 